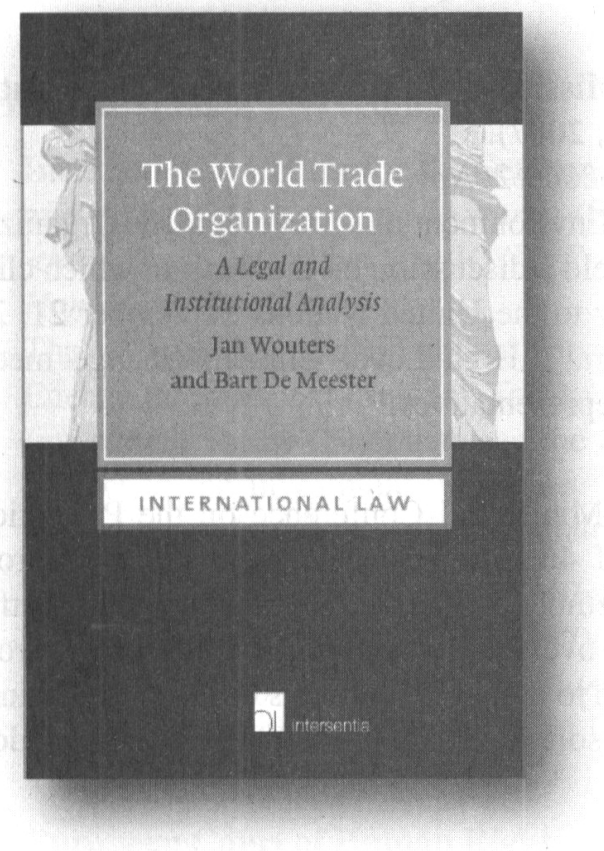

\title{
The World Trade Organization
}

\author{
A Legal and Institutional Analysis
}

Jan Wouters and Bart De MeEster

$\neg$ December 2007

$\neg$ ISBN 978-90-5095-730-4

$\neg \mathrm{xvi}+302 \mathrm{pp}$.

$\neg$ hardcover

$\neg 127.50$ US dollar

The World Trade Organization, set up in 1995, has become a centrepiece of global economic governance in a fragmented international legal and institutional system. The WTO oversees an extensive body of international trade rules. But it has also become a widely contested organization, as its trade rules affect a great variety of rules and policies on environmental protection, public health, technical standards, cultural diversity, financial stability and professional qualifications. Whether it likes it or not, the WTO is put at the centre of global economic governance and no internationally oriented legal practitioner, government official, academic or student can afford to neglect this swiftly developing body of law. This book introduces the institutional and substantive legal aspects of the WTO. It thereby addresses both the vertical interactions of WTO law with domestic legal systems and the horizontal interactions between WTO rules and other areas of international regulation.

Starting from the history and theory of international trade law, the book discusses the content and application of the basic principles in the different WTO agreements. Furthermore, it also clarifies the decision-making processes and dispute settlement system of the WTO.

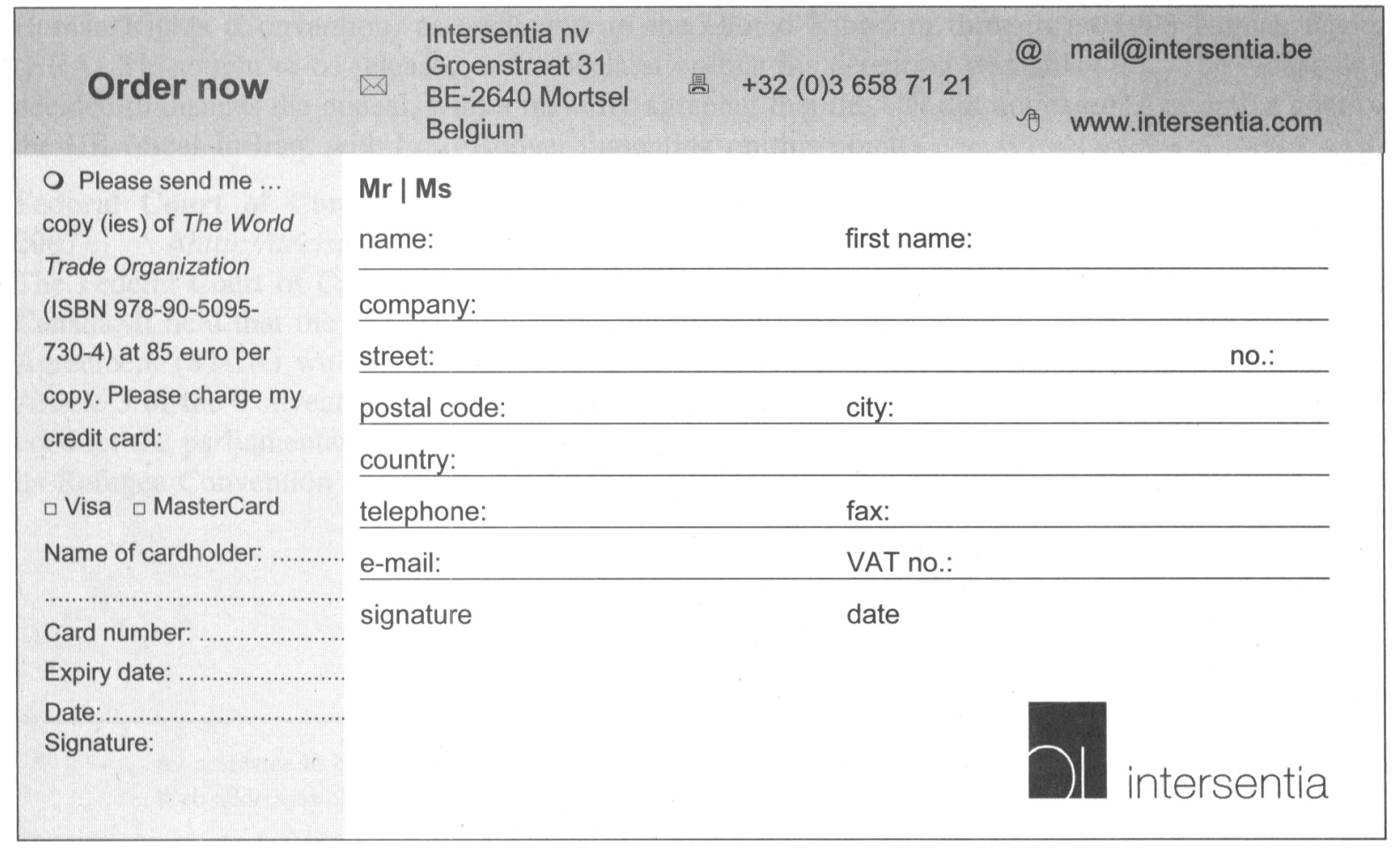




\title{
new from edward elgar publlishing!
}

\section{COMING SOON IN PAPERBACK!}

\section{Elgar Encyclopedia of Comparative}

\section{Law}

\author{
Edited by Jan M. Smits, \\ University of Tilburg, \\ The Netherlands and Tilburg \\ Institute of Comparative and \\ Transnational Law
}

'Comparative law is the comparison of law and legal systems from around the world. At one time it was a field of limited interest and academic participation. However, increasing globalization, whether of commerce or culture, makes it imperative that citizens learn more about the law of other countries. That is the premise of this comprehensive new research tool designed for general readers. Some 70 articles address topics as diverse as accident compensation, legal culture, the European Civil Code, and the law and legal systems of a selected set of nations... This single-volume work provides an excellent comprehensive overview of the current state of affairs in comparative law.'

- J.E. Stephens, Choice:

\begin{abstract}
March 2008840 pp Paperback $9781847206169 \$ 75.00$

2006 Hardback

$9781845420130 \$ 285.00$
\end{abstract}

ELGAR ORIGINAL REFERENCE

\section{The Impact of the WTO}

\author{
The Environment, Public Health and Sovereignty \\ Trish Kelly, Peabody College, Vanderbilt University, US
}

\begin{abstract}
'Kelly's exhaustively researched and highly informative discussion of the nine WTO disputes involving

environmental protection and public health represents

an important scholarly contribution. This book is

the most detailed and sophisticated analysis of the

role of the WTO's dispute mechanisms in addressing

an increasingly important and highly controversial

category of trade disputes.

- David Vogel, University of California, Berkeley, US
\end{abstract}

'Does the WTO favor trade at the expense of national sovereignty, the environment and public health, as the critics contend? Or is it a democratic institution that gives all countries a seat at the table for a feast of free trade? Trish Kelly's superb book, The Impact of

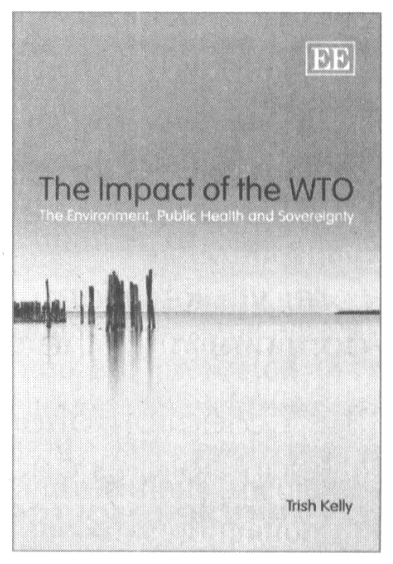
the WTO is the first careful and comprehensive look at the actual environmental and health disputes adjudicated at the WTO to try to answer this question. Her answers are well-researched, objective and unlikely to fully satisfy either side in this sometimes raucous argument: Kelly concludes that, so far, the WTO has not sacrificed sovereignty, the environment and public health; but looking forward, the poorest countries need more assistance to have greater access to the dispute settlement mechanisms. She also shows that strong political action at the national level is necessary to protect public health and the environment. Though controversial, this book will provide the gold standard of careful analysis on these issues for the foreseeable future.

- Gerald A. Epstein, University of Massachusetts, Amherst, US

This volume is the first to provide a comprehensive analysis of the nine environmental and health disputes that have been adjudicated at the WTO since 1995. The investigation concludes that criticism of the WTO has been overstated and, surprisingly, nations do in fact retain sovereignty over environmental and health policy. The disputes explored suggest that the WTO has been able to balance trade, environmental and health objectives. The discussion illuminates the strengths and weaknesses of the dispute resolution process and closes with suggestions for improving it.

2007232 pp Hardback $9781847200815 \$ 90.00$

FROM REST OF WORLD

Marston Book Services Limited PO Box 269

Abingdon, Oxon OX14 4YN UK Tel: +441235465500

Fax:+441235465555

direct.order@marston.co.uk
Edward Elgar Publishing Inc

PO Box 574

Williston, VT 05495-0575 USA

Tel: (800) 390-3149

Fax: (802) 864-7626

eep.orders@aidcvt.com

\section{0}

law

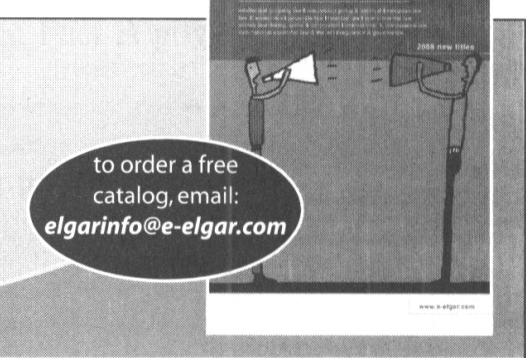

For further infomation, please contact: The Sales and Marketing Department • Edward Elgar Publishing Inc. The William Pratt House 9 Dewey Court • Northampton • MA • 01060-3815 • USA
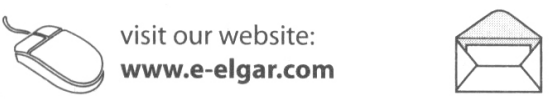

email us:

elgarinfo@e-elgar.com fax us: 


\section{- HeinOnline -}

\section{changing international legal research forever}

\section{Foreign Relations of the United States}

The Foreign Relations of the United States series presents the official documentary historical record of major U.S. foreign policy decisions and significant diplomatic activity.

The series is produced by the State Department's Office of the Historian and is comprised of more than 350 volumes.

Foreign Relations began in 1861 during Abraham Lincoln's administration and continues until the administration of Richard Nixon in 1975.

This collection offers researchers a rare glimpse into the history of this great nation's foreign policies and decisions. Legal scholars of all professions will find this series to be a valuable resource.

\section{Foreign and International Resources Database}

With FILRD, researchers are now able to easily search or browse online through some of the world's best international law publications, including in-depth coverage of publications from ASIL, prominent Yearbooks from around the world, the Hague Permanent Court of International Justice Series and other publications from dozens of highly respected publishers.

Already there are nearly 675 volumes available, that's over 500,000 pages of invaluable legal research information at your fingertips. Future content releases will only continue to enhance this unique database! International legal research has never been easier or more affordable!

All content is image-based (PDF), searchable, printable, comprehensive from inception and affordable for every institution! 


\section{Eleven Presents the Following Titles in European Union Law}

\section{European Union Law:}

\section{Documents ( $2^{\text {nd }}$ edition) \\ edited by Frank Emmert}

$\angle$ This is the second edition of the well-received documents collection on European Union law, first published in 1999. The purpose of this volume is to provide a compact collection of the most important primary and secondary sources of EU law, a quick reference guide, and a desk-copy for rapid and frequent consultation.

This collection differs from other EU document collections as (i) it includes many documents relating to the institutions of the EU and their decision-making process, such as Rules of Procedure of Parliament, Council, Commission and both Courts of the EU; (ii) all regulations and directives are reproduced with their preambles and (iii) all documents are printed with article headlines most of which have been added by the editor.

This collection is volume 1 of a three-volume set on European Union law. Volume 2 covers EU case law and volume 3 is a text book on EU law.

\section{Table of Contents}

Introduction; One: The Foundation of an "Ever Closer Union"; Two: Institutional Law and General Principles of the European Union; Three: Legal Remedies Under EU Law; Four: Human Rights and Civil Liberties; Five: Economic Freedoms in the Internal Market; Free Movement of Goods; Free Movement of Persons; The Freedom to Provide Services and the Freedom of Establishment; Six: European Union Competition Policy; Cartels and Abuses of Dominant Positions; Block Exemption Regulations; Merger Control; Seven: External Trade Law of the European Union; Eight: Other Common Policies of the European Union; Protection of the Environment; Consumer Protection; Labour Law and Social Policy; Index

\section{European Union Law:}

Cases ( $1^{\text {st }}$ edition, reprint)

edited by Frank Emmert

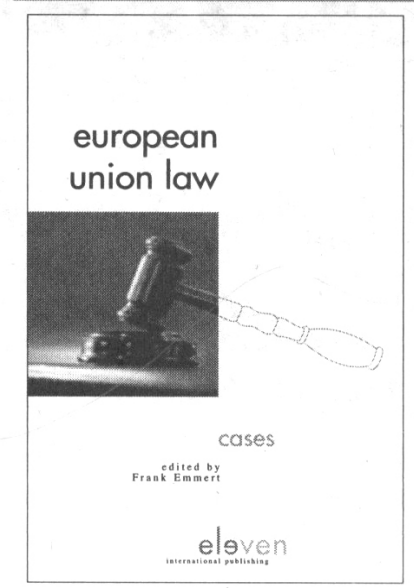

isbn 978-90-77596-28-9

Softbound, xiv +690 pp.

Publication date: Nov.

2007

Price: $€ 49$ / US\$ 75
The purpose of this casebook is to provide students of European integration and all those working with European Union law in practice with a compact collection of the most important judgments in this area. The collection is equally suitable for beginners, who will focus on the "classics", such as van Gend en Loos and Costa v ENEL, and for advanced students in post-graduate programmes who will appreciate to find a good overview of EC competition law and even a number of cases on antidumping and external trade law.

One hundred "leading cases" have been edited and are presented in fifteen chapters to cover the most important areas of Community law. Each case presentation begins with a short and concise summary of the facts. Subsequently, some "questions for consideration" provide guidance for the reading of the judgments. These are followed either by excerpts from the Advocate General's opinion or directly by excerpts from the judgment itself. At the end of many of the leading cases, shorter passages from judgments on related issues help in understanding the development of the Court's case-law over time.

\section{Table of Contents}

Introduction; One: The Foundations of "An Ever Closer Union"; Two: The Institutions of the European Union; Three: Fundamental Principles of European Union Law; Four: Separation of Powers Between the Institutions (Horizontal Distribution of Competences) and Between Union and Member States (Vertical Distribution of Competences); Five: Legal Remedies in National Courts and in the European Court of Justice; Six: The Protection of Human Rights and Civil Liberties in European Union Law; Seven: The Customs Union and the Free Movement of Goods; General Principles; Quantitative Restrictions and Measures Having Equivalent Effect; Discriminatory National Taxes; Eight: The Free Movement of Employed Persons; Nine: The Movement and Establishment of Self-Employed Persons and Companies; Ten: The Free Movement of Services; Eleven: Mutual Recognition of Diplomas and Professional Qualifications; Twelve: Competition Law; Thirteen: European Environmental Law; Fourteen: External Relations of the European Union; Fifteen: The Common Commercial Policy; Table of Case; Index

Eleven International Publishing is a new international legal publishing company, based in the Netherlands. ELEVEN's aim is to support the use of international law by offering high quality and timely publications. ELEVEN is active in various areas of law. Please visit our website www.elevenpub.com for more Please contact our office or order from your bookseller Eleven International Publishing

3500 AJ Utrech

The Netherland

$\mathrm{F}:+31(0) 30225804$

sales@elevenpub.com

\section{ISBS, 920 NE 58th Avenue, Suit}

Tel. toll-free: (1) 8009446190

orders@isbs.com, www.isbs.com 


\section{New fro
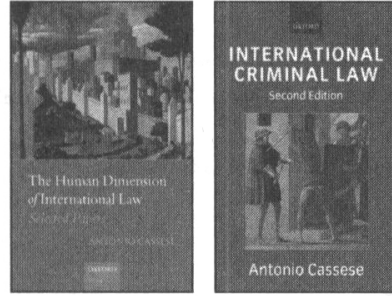

INTERNATIONAL LAW

Chittharanjan F. Amerasinghe, Member, Institute de Droit International; former Judge, UN Tribunal, New York

Offers a completely up-to-date juristic exposition and analysis of diplomatic protection as an institution of public international law.

(Oxford Monographs in International Law)

2008300 pages

978-0-19-921238-5 cloth $\$ 110.00$

Winner of the Wolfgang Friedmann Memorial Award for outstanding contributions to the field of international law

The Human Dimension of

International Law

Selected Papers of Antonio Cassese

Antonio Cassese, Professor of International Law,

University of Florence Paola Gaeta and

\section{Salvatore Zappalà}

This book collects the most important papers of Antonio Cassese, the first President of the

International Criminal Tribunal for the former Yugoslavia and chairman of the UN Commission of Inquiry into the crimes committed in Darfur. 2008700 pages

978-0-19-923291-8 cloth $\$ 130.00$

International Criminal Law

Second Edition

Antonio Cassese, Professor

of International Law, University

of Florence

The most popular textbook available in

the field, providing a concise introduction to both international criminal law and international criminal procedure from its leading expert. Cassese provides a uniquely personal perspective that brings the subject to life.

2008550 pages

978-0-19-920310-9 pape

$\$ 70.00$
Diplomatic Protection

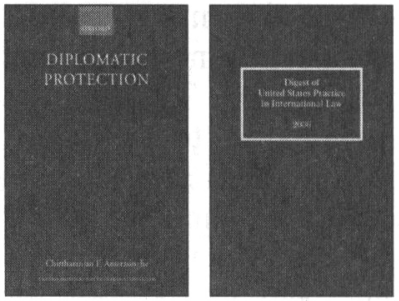

Digest of United States Practice in International Law Series

Edited by Sally J. Cummins, Office of the Legal Adviser, U.S. Department of State.

"No international law library is adequate without it." -Davis Robinson, of counsel, LeBoeuf, Lamb, Greene \& McRae, LLP; Former Legal Adviser to the US Department of State.

Digest of United States Practice in International Law, 2006

$2008 \quad 1,420$ pages

978-0-19-533948-2 cloth $\$ 145.00$

Digest of United States Practice in International Law, 2005

$2007 \quad 1,270$ pages

978-0-93-532899-8 cloth $\$ 145.00$

Digest of United States Practice in International Law, 2004

20061,280 pages

978-0-935-32898-1 cloth $\$ 145.00$

Cumulative Index

2008526 pages

978-0-19-533947-5 cloth

$\$ 145.00$

\section{INTERNATIONAL TRADE}

International Trade in Services and

Domestic Regulations

Necessity, Transparency and

Regulatory Diversity

Panagiotis Delimatsis, Senior Research

Fellow at the World Trade Institute, University of Berne, Switzerland

This volume maps a clear horizontal legal framework for the international regulation of trade in services across all service sectors and combines a thorough analysis of the WTO case-law with an analysis of the economic and political economy considerations that shape the development of service regulation.

(International Economic Law Series)

$2008 \quad 375$ pages

978-0-19-953315-2 cloth $\$ 120.00$

To order, or for more information, please contact customer service at 1-866-445-8685 $\mathrm{OXFORD}$ or visit us online at www.oup.com/us. 


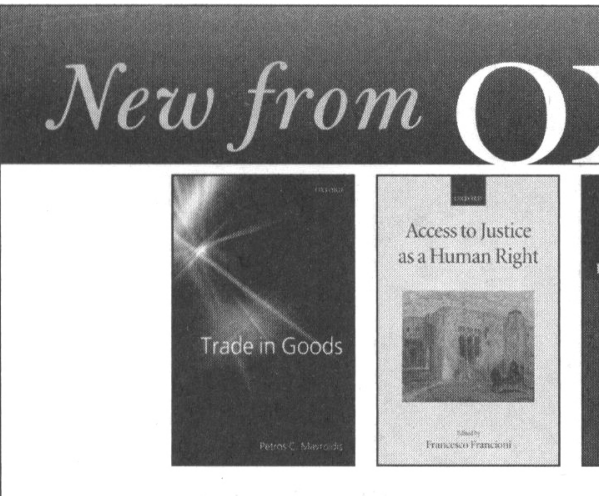

Trade in Goods

An Analysis of International

Trade Agreements

Petros Mavroidis, Professor of Law at Columbia Law School and the University of Neuchatel

This book analyzes the establishment and operation of international agreements regulating trade in goods, focusing on the General Agreement on Tariffs and Trade (GATT).

2007500 pages

978-0-19-923903-0 cloth $\$ 150.00$

\section{HUMAN RIGHTS}

Access to Justice as a Human Right Edited by Francesco Francioni, Professor of International Law and Human Rights at the European University Institute, Florence

This unique collection of essays provides an overview of the problems at the heart of providing access to justice in international law and covers diverse subjects including environmental justice, situations of armed conflict, and access to justice for torture victims and terrorist suspects.

2007300 pages

978-0-19-923308-3 cloth $\$ 120.00$

978-0-19-923309-0 paper $\$ 45.00$

\section{Regional Protection of Human Rights}

Dinah Shelton, Professor of Law at George Washington University Law Schoo

"This book is a welcome addition to the International Human Rights canon and a crowning achievement. It will be an invaluable desk reference for any student, scholar or practitioner of international human rights and provides an excellent vehicle for teaching an introductory or advanced course on the subject." -Beth Van Schaack, Santa Clara University School of Law

$2008 \quad 1,168$ pages

978-0-19-537165-9 pack (main volume and documentary supplement) $\$ 195.00$

$978-0-19-533339-8 \quad$ cloth (main volume) $\$ 125.00$ 9780195333404 paper (documentary supplement) $\$ 70.00$

\section{FORD}
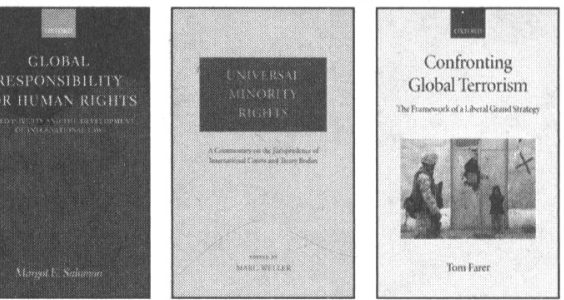

Global Responsibility for Human Rights

Margot E. Salomon, Lecturer in Law at the Centre for the Study of Human Rights and the Department of Law, London School of Economics and Political Science Foreword by

\section{Stephen P. Marks}

This book considers the evolving nature of public international law and human rights with respect to international cooperation as a basis for addressing the role and responsibility of the international community in the creation of an environment conducive to a human-centered globalization.

2008250 pages

978-0-19-928442-9 cloth $\$ 110.00$

Universal Minority Rights

A Commentary on the Jurisprudence of International Courts and Treaty Bodies

Marc Weller, Director of the European Centre for Minority Issues

This volume clarifies and develops the principles and substantive standards involved in minority rights -

from the definition of minority itself to the meaning of religious freedom.

2008504 pages

978-0-19-920851-7 cloth $\$ 99.00$

\section{ARMED CONFLICTS AND TERRORISM}

\section{Confronting Global Terrorism}

The Framework of a Liberal Grand Strategy

Tom Farer, Dean, Graduate School of International Studies, University of Denver

"Tom Farer has written a passionate, reasoned case for a liberal grand strategy of containment which will enable America and her allies to master the challenges of the 21st century-terrorism."-Michael Ignatieff, MP, House of Commons, Canada(Collected Courses of the Academy of European Law)

2008300 pages

978-0-19-953472-2 cloth $\$ 80.00$ 978-0-19-953473-9 paper $\$ 29.95$ 


\section{INVALUABLE NEW LAW BOOKS FROM HEIN!}

American Journal of International Law

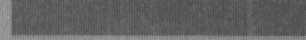

\section{American Journal of International Law (AJIL) CUMULATIVE INDEX 1991-2000, Volumes 85-94}

"A-Rated" - AALS Law Books Recommended for Libraries, List 46, International Law, Page 3

The distinguished $A J I L$ has been published quarterly since 1907. It features articles, editorials, notes and comments by pre-eminent scholars on developments in international law and international relations. This cumulative index spans ten years and includes a Table of Cases, Subject Index, Author Index and Title Index. It is indispensable for all professionals in international aw, economics, trade and affairs.

\section{Law of the International Criminal Court}

Young Sok Kim

As one of the Korean delegates to the Rome Conference in 1998 that established the ICC, the author is intimately familiar with matters related to the ICC's formation. This work addresses a host of difficult and common questions about the ICC and also records some legislative histories of important articles of the ICC Statute.

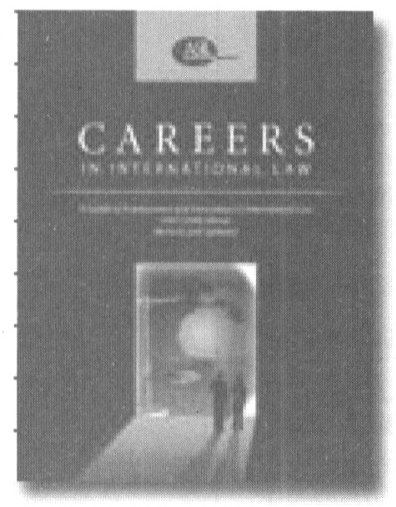

\section{CAREERS IN INTERNATIONAL LAW: A Guide to Career Paths and Internships in International Law (2007-2008 Edition)}

The Guide is a valuable resource for any student or new professional considering a career in international law. It contains essays, in which seasoned practitioners share their experiences and offer advice concerning career paths in public and private international law fields, such as criminal, human rights, international trade and much more.

\section{WTO LAW, LITIGATION AND POLICY: Sourcebook of Internet Material Stuart S. Malawer}

This outstanding sourcebook of Internet documents on WTO law and the dispute resolution system is a tremendous resource. With its comparative and institutional focus as well as its inclusion of interdisciplinary information on issues of law, trade and politics from a range of member states, it will be invaluable to governments and professionals worldwide. Its reliance on material available on the Internet provides evidence of the growth of the historical revolution in information and communications technology that coincides with the birth and growth of the WTO itself.

Email us today to receive your copies of these great international law resources! 


\section{Meet yournew research team.}

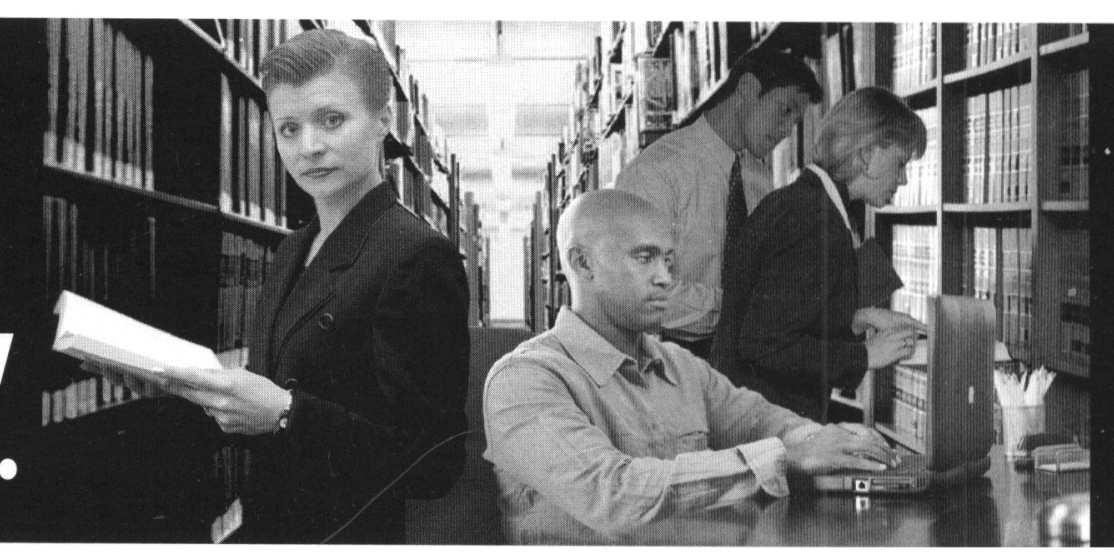

A team of experienced librarians and legal research experts is working for you, and you didn't even know it. Better yet, you can call on them 24 hours a day, seven days a week.

The EISIL team has broken down the complicated world of researching international law into 13 broad categories covering 300 international law topics. At www.eisil.org, you'll have easy access to:

- Primary source documents such as treaties and agreements.

- Information for cite checking international legal materials for articles, briefs, and working papers.

- The best web sites and other tools for doing further research on an international topic.

Research that used to take days or hours and required an extensive library can now be done in minutes!

Try it. EISIL is fast, easy and FREE. Your team of researchers is waiting.

Check out EISIL today at www.eisil.org

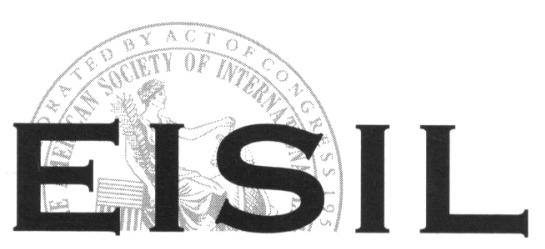

Electronic Information System for International Law

EISIL was developed by the American Society of International Law under a grant from the Andrew W. Mellon Foundation. 


\section{INTERNATIONAL LAW: 100 WAYS IT SHAPES OUR LIVES}

Many find international law abstract and static. Topics such as war and peace or relationships between countries are considered by some to be not so much questions of law, but of power and influence. Others question the existence of international law.

International Law: 100 Ways It Shapes Our Lives was conceived from the proposition that international law not only exists, but also penetrates more deeply and broadly into everyday life than is generally recognized. Some ways are of relatively recent vintage, while others are long-standing. 100 examples were identified by ASIL members, vetted by a smaller group of experts, and organized into seven chapters: 1) daily life; 2) leisure; 3) travel; 4) commerce 5) health and the environment; 6) personal liberty; 7) public safety and global security.

Join us in demonstrating how international law shapes our lives by

- Visiting 100 Ways at http://www.asil100.org/ways.html;

- Using it in teaching and general civic education programs;

- Adding ways to the list; and

- Sharing your experiences using International Law: 100 Ways it Shapes Our Lives.

We hope that this creative and interactive project will help demonstrate the diversity and the centrality of international law to our lives today.
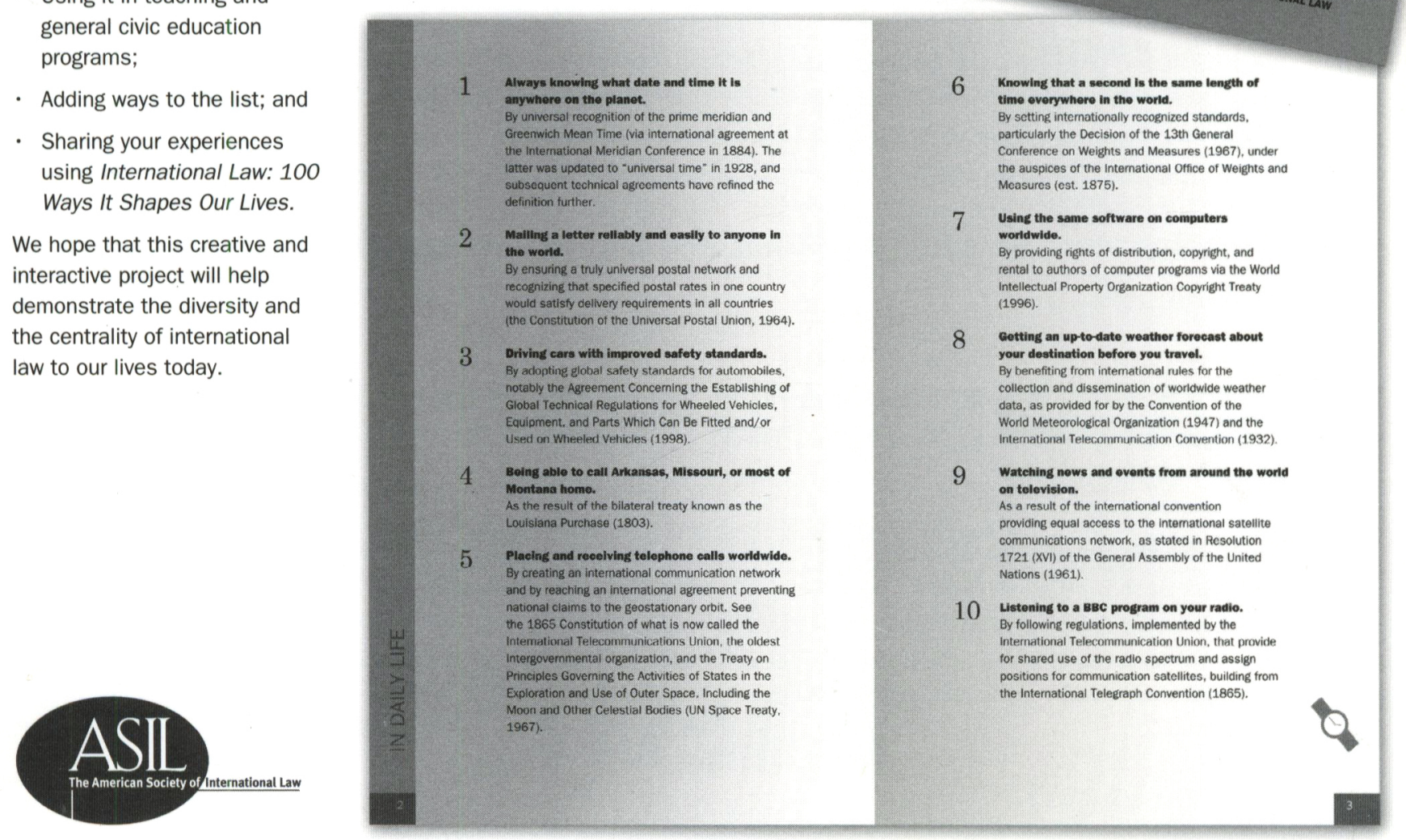

w w w a sil 100.0 rg 